\title{
Agricultural and Food E-Resources Usage at the University of the West Indies (UWI) Mona Campus
}

\author{
West Indies Universitesi (UWI) Mona Kampüsü'nde Tarım ve \\ Gıda E-Kaynakların Kullanımı
}

\author{
Sasekea Yoneka HARRIS*
}

\begin{abstract}
An analysis of selected agricultural and food e-resources at UWI Mona Campus indicate only a small percentage of students and lecturers are utilizing these.

These statistics are alarming for a number of reasons, namely: (a) the high cost of these e-resources; (b) the value in e-resources as posited by authors; (c) the reality that e-resources are $a$ feature of the Web 2.0 age in which we currently reside; (d) and quality reviewers' and accreditation board members' expectations of universities to provide e-resources. If it is that e-resources are so valuable and are a feature of the Web 2.0 era and yet they are being underutilized, this has clear implications for research throughput in respect of such matters as: term papers, lectures and publications in agricultural and food sciences. Additionally, the low usage threatens the viability of continuing the provision of these e-resources at UWI. Using the UWI Mona Campus population this paper seeks to provide an understanding of the reasons for the current usage patterns; the implications for collection management as well as for research throughput; and the ways in which greater usage can be encouraged.
\end{abstract}

Keywords: Agricultural and Food E-Resources, University of the West Indies (UWI), E-Resources

\section{Öz}

UWI Mona Kampüsü'nde seçilmiş tarım ve gıda e-kaynaklarının kullanım analizi, öğrencilerin veöğretim elemanlarının sadece küçük biryüzdesibu kaynaklardan yararlandığını göstermektedir.

Çalışmada sunulan istatistiki veriler; (a) Illgili e-kaynakların yüksek maliyeti; (b) yazarlar tarafından seçilen e-kaynakların değeri; (c) E-kaynakların şu anda içinde bulunduğumuz Web 2.0 çağının özelliklerini taşıması; (d) ve kalite kontrolü ve akreditasyon kurulu üyelerinin e-kaynak tedariğinde üniversitelerden beklentileri açılarından önem taşımaktadır. Bu e-kaynakların Web 2.0 çağının gerektirdiği özellikte olmasına karşın az kullanılması, tarım ve gıda bilimleri alanında dönem ödevlerini, ders materyallerini ve genel olarak yayınları acık bir şekilde etkilemektedir. Ayrıca, düşük kullanım UWI'de ilgili e-kaynakların sağlanmasında sürekliliği tehdit etmektedir. Bu

* Dr.; University of the West Indies, Mona Campus, Jamaica W.I. (sy_harris@hotmail.com) 
araştırma UWI Mona Kampüsünde ilgili e-kaynakların mevcut kullanım durumu, derme yönetimi, araştırma verimi ve daha fazla kullanımı teşvik etmek için yapılması gerekenler üzerine genel bir bakış sağlamayı amaçlamaktadır.

Anahtar sözcükler:: Tarım ve gıda e-kaynakları, West Indies Universitesi(UWI), E- kaynaklar

\section{Introduction}

The UWI is the premiere university in the Caribbean. It comprises campuses in Cave Hill, Barbados; St. Augustine, Trinidad; Mona, Jamaica; and an Open Campus. The UWI Mona Campus, which is the focus of this paper, has an enrollment of approximately 11,000 students and offers various programs at the undergraduate, graduate and postgraduate levels in Humanities \& Education, Medicine, Law, Social Sciences and Science \& Technology. The UWI Mona libraries serve as the information hub for these offerings by providing vital material in print and electronic formats in support of teaching, learning and research. The benefits of e-resources and library quality assurance reviewers' expectations that libraries provide these encourage libraries to subscribe to e-resources. However, current usage patterns amidst soaring costs and competition for scarce financial resources raise questions about the returns on these resources given the financial outlays on them. This is a point that was underscored in UWI Mona library's periodic review. The review panel noted:

While faculty, students and staff are generally aware of the dire financial situation, their expectation that the Library should be the primary source of teaching and learning materials and that these materials should be made available in multiple copies in printed form remains strong. Reluctance, on the part of some faculty and students, to use the online resources that the Library offers and will increasingly offer, is counterproductive to the academic success of the University and its constituents. Acknowledging that reading and studying materials online is still challenging to many individuals, it is also important to recognize that scholarly materials will increasingly be available online both for purchase and for free, and that printed materials will become less popular and less available. (Law, Hemmasi, Baxmeyer, 2012, p. 12)

To add to this there has been a renewed focus on food security and the nexus with development in Jamaica. Consequently, increasing agricultural productivity is being consistently reiterated and is being given greater prominence. Understandably, these trends raise particular concerns for a science librarian especially with respect to the usage and financial tenability of agricultural and food science e-resources and hence the motivation for research in this area. Accordingly, this paper looks at: (1) usage of select e-resources; (2) reasons for current usage; (3) implications of usage; and (4) measures to increase usage. Given the nature of these objectives a quantitative approach was used. This involved collecting statistics from the database vendors to determine usage; administering questionnaire to a purposive sample of students and lecturers 
to establish the reasons for current usage patterns and the ways in which usage can be increased; and SPSS and measures of central tendency were used to analyze the data and determine the implications of usage. This paper is therefore of value because (1) it provides the UWI Mona library with feedback on select food and agricultural e-resources, (2) usage patterns (3) measures to improve usage (4) and it informs future selection of e-resources in agriculture and food. In terms of an outline, the first section of this paper reviews the literature relating to: database usage, reasons for usage, the implications of usage and the ways in which greater use can be encouraged. The second section presents the methodology, results and analysis of the review of the usage of two highly promoted databases at UWI. The final section contains the conclusion, recommendations and references.

\section{Literature Review}

Law et al. (2012, p. 12) indicated a number of benefits of e-resources. These included: "broader access for the campus community to current, top-quality materials; a potential for reduced spending by focusing on open access materials that are free of charge". They also added that by eliminating print-based subscriptions that duplicate the online versions this would relieve the overcrowded library shelves as print equivalents that are available online would be discarded. This they advised would lead to: "reduction in purchasing, processing, shelving, circulating, and repairing printed materials; reclaimed space in the libraries for user study and group collaboration; and preparing students to live and learn in the 21 st century world" (Law et al., 2012, p. 12). According to Salisbury, Laincz and Smith (2012, p. 250) "in the sciences, faculty, researchers and graduate students are heavily dependent on subscription databases and other resources to support their research and educational programs". This section will review the extent to which this is consistent in libraries, the reasons, the implications and suggestions for increased usage. Further, this research will determine the extent to which this is the situation at the UWI Mona Campus.

\section{Usage Reports}

The literature provides mixed reports regarding the usage level of electronic databases. Some studies reported high usage such as: Bar-llan and Fink (2005); Dilek-Kayaoglu (2008, p. 246) and Yue and Syring (2004, p. 431); while others reported low usage such as: Coombs (2005, p. 603); Atilgan and Bayram (2006, p. 89); and Dewald \& Silvius (2005, p. 325). These contrasting reports on levels of usage raise some important questions for research on database evaluation. What are the methods used to assess usage? Is usage meaningful usage or inflated usage? How does one address potential inflation? In this regard libraries need to determine their measure of meaningful usage. Is it simply counting the number of search sessions or the number of searches or the number of full text articles downloaded? Will these be used independently or will the librarian match these with student enrollment and the number of lecturers on staff and the expected 
usage by each group vis à vis the actual usage. This paper takes these implications into consideration. Together, these usage reports raise another important issue: dependence on vendor statistics or library generated statistics? Which is more robust? Coombs (2005, p. 600) research provided a direct response. It states the former is not robust enough (Coombs, 2005, p. 600). Additionally, the usage reports highlighted the purposes for using databases. Tenopir, King, Boyce, Grayson, Zhang, \& Ebuen (2003), Bar-llan \& Fink (2003, p. 354), Dewald \& Silvius (2005, p. 325) all indicated that databases were primarily used for professional and scholarly purposes rather than personal needs. The literature also suggests that knowledge of databases is not synonymous with use. For example, although in Atilgan and Bayram's (2006, p. 88) study 1727 reported they had knowledge about the contents of electronic databases 20.5 percent reported that they did not use these resources while, 52.0 percent of respondents reported occasional use, and 27.5 percent reported using these databases frequently". It is also interesting to note that two studies indicated lower usage of Science Direct as oppose to other databases such as Ebsco (Atilgan and Bayram, 2006, p. 90; Coombs, 2005, p. 603). This is particularly interested as this research examines usage of Science Direct and Ebsco.

\section{Reasons for Usage Patterns}

A review of the literature reveals two major findings with regards to the reasons for usage. Firstly, the choice between using the library's electronic databases versus other information resources is largely determined by three factors, namely: (a) library related factors: For example Coombs (2005, p. 603) noted a correlation between the usage of databases and the databases being taught as part of the library's information session as reason for usage. (b) patron related factors. For example lack of knowledge on the patron's part with regards to using the databases (Salisbury et al., 2012, p. 251). (c) Information source related factors (features versus content). This is evident in studies such as: Griffiths and Brophy (2005); Fast and Campbell (2004, p. 138); Brophy (2005, p. 499, 509-510); Salisbury et al., (2012, p. 256, 258); and Coombs (2005, p. 603). Together their studies found that the reasons students choose Google Scholar over library databases are: ease of use, accessibility, convenience, quickness and familiarity; information architecture, menus and labeling, navigation, usability of the database. Those who selected library databases noted:"pertinent to most of the research work I do", consistently provide peer reviewed journals, can search a huge catalog of journal articles; trusted content and specificity (Salisbury et al., 2012, p. 262-263). These studies reveal that users primarily report that they choose Google because of features and on the contrary often report they choose library databases for content rather than reporting they choose library databases for features.

Secondly, the review indicated that Google and Google Scholar provide solid competition for library electronic databases. According to Bell (2004), "Google has become the symbol of competition to the academic library". Similarly Brophy (2005, p.509) notes "the two kinds of resource- search engines and library databases - seem to be complementary". 


\section{Implications of Usage}

The extent to which the electronic databases are used has implications for selection, continuity and communication, the nature of collection development and research throughput, and students' access to technology.

a. Selection, Continuity \& Communication: The literature showing high usage suggests libraries should continue subscription to electronic databases but not without the proviso that consideration should be given to the possibility for inflated usage and the need to create meaningful usage criteria. The literature showing low usage indicates a need for librarians to evaluate the databases that they have chosen. There is the intimation that they should consider: cancelling all, or cancelling some, or re-selecting the current preferred options. However, a determination will be needed as to the option that will be used to guide these decisions: usage based evaluation vs. collection based evaluation.

b. Collection Development \& Research Throughput: Elitist or for the Mass?: The UWI Mona library review team heard conflicting accounts about the level of access to information technology and the Web that is available to students both on and off campus. Consequently, they contend:

It would be useful for the University to undertake a review of students' access in order to better understand and plan for actual needs. Some of the information that would feed into planning for the Library's future includes reliable information about the percentage of students with laptops, with cell phones or other mobile devices, and with Internet access at home. Results of such a survey could have considerable influence on the Library's decisions about the appropriate format of information resources and how they are to be disseminated. (Law et al., 2012, p. 5)

If it is that students access to personal computers and Internet access at home are questionable and the library continues to provide electronic databases this may raise questions on who libraries are providing resources for and in this regard are they supporting elitist education or education for the mass through their collection development practices? Are they widening the information gap or are they helping to close the information gap? If the resources are largely online and students do not have the tools to access these, what kind of term papers will they produce? Which group of students will consistently be able to access these resources?

\section{Encouraging Greater Use}

The literature makes a number of recommendations regarding increasing usage of electronic databases in the academic environment. Regardless of the quantity of these initiatives, the literature, for example, Law et al., (2012, p. 12); Coombs' (2005, p. 604) (Sample, 2012); Atılgan \& Bayram (2006, p. 90); Salisbury et al., (2012, p. 251); and Dewald \& Silvius (2005, p. 325) seem to point to the role of three key players, namely: the university administration, faculty and the library. 


\section{Methodology and Demographics of the Study}

Among the techniques to evaluate databases, user-based techniques are the most often used and the most easily applied (Dilek-Kayaoglu, 2008, p. 240). Accordingly, the study used data gathered from Elsevier's Science Direct full text usage report files for selected food and agricultural journals for the years 2010-2012. It also used data from Ebscohost's usage report files for Agricola database, which is an abstract only agricultural database which connects users to full text articles in the other Ebsco databases subscribe to by UWI. Ebsco and Science Direct were selected because they are usually emphasized in information literacy sessions. Coombs' (2005, p. 603) observation of a correlation between the usage of databases and the databases being taught as part of the library's information session supports this selection. In this regard, these resources should be a good indicator of usage. The usage statistics were then analyzed using measures of central tendency. Given that the Mona libraries are part of the larger UWI system, which comprises: Mona, Cave Hill, St. Augustine and Open Campus; the statistics reflect usage for the entire UWI system rather than for only the Mona libraries. In this regard, the analysis of the vendor statistics on usage is done with this in mind. The vendor statistics therefore primarily answered the first research question/objective, which is on level of usage.

"Usage data provided through the database vendors are not robust enough to meet the library's need" (Coombs, 2005, p. 600). As such, this research also collected data from a survey of core students and lecturers in food and agriculture at the UWI Mona Campus. Questionnaires were also used in order to highlight the Mona campus only, as the vendor statistics do not consistently provide this. Further, given that only select e-resources from Ebsco and Science Direct were used, the questionnaires will highlight whether Mona users used the other e-resources provided by UWI and/or or outside of UWI. In this study core Mona student population is defined as the total number of majors and minors in food chemistry, food processing, agriculture and horticulture at the undergraduate and graduate levels at Mona. In this study core Mona lecturer population is defined as the total number of academic staff facilitating the teaching of food chemistry, food processing, agriculture and horticulture at the undergraduate and graduate levels at Mona. Purposive sampling was used to select the students and lecturers. As such, the questionnaires were issued during lecture periods to those present, available and willing. Tables I-III, which follow, show the population and the sample size selected.

Table I. Student Sample Used for the Questionnaire

\begin{tabular}{cccc}
\hline Year & Core Mona Student Population & Sample & Sample \% \\
\hline $\mathbf{2 0 1 2}$ & 55 & 42 & 76.3 \\
\hline
\end{tabular}


Table II. Lecturer Sample Used for the Questionnaire

\begin{tabular}{cccc}
\hline Year & Core Mona Lecturing Population & Sample & Sample \% \\
\hline $\mathbf{2 0 1 2}$ & 25 & 8 & 32 \\
\hline
\end{tabular}

Table 3, which follows, shows that a total of 50 persons were sampled, with the following breakdown: $60 \%$ undergraduates, $24 \%$ postgraduates and $16 \%$ lecturers.

Table III. Total Sample Used for the Survey

\begin{tabular}{lrr}
\hline & Frequency & Percent \\
\hline Undergraduate & 30 & 60.0 \\
Postgraduate & 12 & 24.0 \\
Lecturer & 8 & 16.0 \\
Total & 50 & 100.0 \\
\hline
\end{tabular}

The questionnaire comprised 10 questions and was used to collect information on usage (questions 1-4); reasons for usage (questions 5-8); implications of usage (questions 1-8); and recommendations for encouraging greater use (question 9).

\section{Results and Discussion}

The results and discussion are presented by research questions/objectives, namely: (i) database usage, (ii) reasons for usage, (iii) implications, and (iv) recommendations for greater usage. Accordingly, the first section presents the usage report for food and agriculture in Science Direct for the period 2010-2012; then for Ebsco's Agricola for the period 2010-2012; and then the usage report from the questionnaire (questions 1-4). The second section presents data from the questionnaire as it relates to the reasons for usage (questions 5-8). The third section presents the implications of the usage reported and the response for this is drawn from the previous sections. The fourth section presents the recommendations for greater use from the questionnaire (question 9).

\section{Database Usage}

Table 4 shows that for the period 2010-2012 the most used journals were:

$\diamond$ Journal of Food Engineering

$\diamond$ Food Chemistry

$\diamond \quad$ Field Crops Research

$\diamond \quad$ Animal Reproduction Science 
Table IV. Food \& Agriculture in Science Direct: Usage Report 2010-2012

\begin{tabular}{|c|c|c|c|}
\hline Name of Journal & 2010 & 2011 & 2012 \\
\hline Agricultural Systems & 91 & 72 & 119 \\
\hline Animal Behavior & 162 & 130 & 151 \\
\hline Animal Reproduction Science & 1439 & 144 & \\
\hline Agricultural Water Management & & & 1 \\
\hline Agriculture Ecosystems \& Environment & & & 2 \\
\hline Animal Feed Science and Technology & & & 4 \\
\hline Animal Reproduction Science & & & 44 \\
\hline Carbohydrate Research & 221 & 192 & 290 \\
\hline Clinical Nutrition & 37 & 52 & 57 \\
\hline Clinical Nutrition Supplements & & 1 & \\
\hline Computers and Electronics in Agriculture & & & 2 \\
\hline Field Crops Research & 1030 & 91 & 51 \\
\hline Food and Bioproducts Processing & & & 1 \\
\hline Food and Chemical Toxicology & & & 4 \\
\hline Food Chemistry & 200 & 1274 & 1342 \\
\hline Food Control & & & 2 \\
\hline Food Policy & 1 & & \\
\hline Food Microbiology & & & 1 \\
\hline Food Research International & & & 1 \\
\hline Industrial Crops and Products & 14 & & \\
\hline Innovative Food Science \& Emerging Technologies & & & 4 \\
\hline International Journal of Food Microbiology & 1 & & 2 \\
\hline Journal of Agricultural Engineering Research & & 8 & 15 \\
\hline Journal of Food Composition and Analysis & & & 2 \\
\hline Journal of Food Engineering & 1043 & 383 & 485 \\
\hline Journal of the Academy of Nutrition and Dietetics & 0 & 0 & 24 \\
\hline Journal of the American Dietetic Association & 78 & & 278 \\
\hline Livestock Production Science & 33 & 39 & 28 \\
\hline Livestock Science & 49 & 33 & 56 \\
\hline Nutrition & 71 & 174 & 156 \\
\hline Nutrition Research & 102 & 102 & 58 \\
\hline
\end{tabular}




\begin{tabular}{lrrr} 
Postharvest Biology and Technology & 225 & 86 & 162 \\
Scientia Horticulturae & 244 & 284 & 166 \\
Soil and Tillage Research & 197 & 116 & 63 \\
Soil Biology and Biochemistry & 102 & 126 & 132 \\
Trends in Food Science and Technology & 122 & 159 & 204 \\
Trends in Plant Science & 107 & 103 & 97 \\
\hline TOTAL & $\mathbf{5 5 6 9}$ & $\mathbf{3 5 6 9}$ & $\mathbf{4 0 0 4}$ \\
\hline
\end{tabular}

The least used journals were:

$\checkmark$ Agricultural Water Management

$\checkmark$ Agriculture Ecosystems \& Environment

$\checkmark$ Animal Feed Science and Technology

$\checkmark$ Animal Reproduction Science

$\checkmark$ Clinical Nutrition Supplements

$\diamond \quad$ Computers and Electronics in Agriculture

$\checkmark$ Food and Bioproducts Processing

$\checkmark$ Food and Chemical Toxicology

$\checkmark$ Food Control

$\checkmark$ Food Microbiology

$\checkmark$ Food Policy

$\diamond$ Food Research International

$\diamond$ Industrial Crops and Products

$\checkmark$ Innovative Food Science \& Emerging Technologies

$\diamond$ International Journal of Food Microbiology

$\checkmark$ Journal of Agricultural Engineering Research

$\checkmark$ Journal of Food Composition and Analysis

Table IV further indicates the other journals had intermittent use. For the year 2010 the average download was 242.13 (total full text downloaded / no. of journals); for 2011, the average download was 169.95 and for 2012, the average download was 121.33. For the year 2010 the average download per month was 20.17 (total full text downloaded / no. of journals / 12 months); for 2011, the average per month download was 14.16 and for 2012, the average per month download was 10.11. This is presented in table 5, which follows: 
Table V. Average Download Per Year \& Month for Food \& Agricultural E-Resources in Science Direct

\begin{tabular}{ccc}
\hline Year & Average Download Per Year & Average Download Per Month \\
\hline $\mathbf{2 0 1 0}$ & 242.13 & 20.17 \\
$\mathbf{2 0 1 1}$ & 169.95 & 14.16 \\
$\mathbf{2 0 1 2}$ & 121.33 & 10.11 \\
\hline
\end{tabular}

Table $\mathrm{V}$ indicates a downward trend in usage per year. The total average full text download per month for the period 2010-2012 was 14.81. These can be given further meaning by comparing the actual usage per year with the total core food and agriculture student population and the expected usage by this group. In this study, the total core food and agriculture population is defined as the total number of majors and minors in food chemistry, food processing, agriculture and horticulture at the undergraduate and graduate levels for all campuses. See Table VI, which follows.

Table VI. Total Core Food \& Agriculture UWI Student Population

\begin{tabular}{rrrr}
\hline Year & St. Augustine & Mona & Cave Hill \& Open Campus \\
\hline $\mathbf{2 0 1 2}$ & 769 & 55 & 0 \\
$\mathbf{2 0 1 1}$ & 807 & 87 & 0 \\
$\mathbf{2 0 1 0}$ & 777 & 28 & 0 \\
\hline TOTAL & $\mathbf{2 3 5 3}$ & $\mathbf{1 7 0}$ & $\mathbf{0}$ \\
\hline
\end{tabular}

With regards to expected usage, if it is that:

$\checkmark$ "scholarly materials will increasingly be available online" (Law et al., 2012, p. 12);

$\diamond$ graduate students are expected to be heavily dependent on subscription databases and

$\checkmark$ indeed we are living in the Web 2.0 era;

It is fair to expect that undergraduates should be downloading at least 2 articles per month and postgraduates should be downloading a minimum of 5 articles per month, bringing the expected average download of articles by both groups to 3.5 per month. With these expectations, it can be inferred that for the year 2010 the shortfall between the expected usage per month and the actual usage per month was $83.8 \%$; for the year 2011 the shortfall was $90.4 \%$; and for the year 2012 the shortfall was $88.4 \%$. These figures are indicative of extreme low usage. Further, if it is that only the core food and agricultural student population was used, this raises concerns on the shortfall that would have been highlighted had the core lecturer population been added to these figures; it is fair to infer that the usage would even be lower. 
Formula for Calculating the Shortfall between the Expected Usage per month \& the actual usage per month:

$\diamond$ Total no. of students * Estimated usage per year for both groups $=$ Total Expected Usage;

$\diamond \quad$ Total Expected Usage / No. of journals per year / No. of months = Average expected download per year;

$\diamond \quad$ Average expected download per year - Actual download per year $=x$; $\mathrm{X}$ *100 $=\%$ Difference between expected usage \& actual usage

Average Expected Download per year

Table VII. Agricola (Ebscohost): Usage Report 2010-2012

\begin{tabular}{lrr}
\hline Year & Sessions & Smart Link From \\
\hline 2010 & 40 & 9 \\
2011 & 5562 & 71 \\
2012 & 5411 & 90 \\
\hline TOTAL & $\mathbf{1 1 , 0 1 3}$ & $\mathbf{1 7 0}$ \\
\hline
\end{tabular}

If it is that the expectation is an average of 3.5 articles download per month, it follows that students would require a minimum of 1 session per month to retrieve these monthly full text articles. In this regard, this indicates that for the year 2010 the shortfall between the expected sessions and the actual sessions done was $99.5 \%$; for 2011 , the shortfall was $48.1 \%$ for the year and for 2012 , the shortfall was $45.2 \%$.

Formula for Calculating the Shortfall between the Expected Sessions Per Year and the Actual Sessions Per Year:

$\diamond \quad$ No. of students * Expected no. of sessions per year $=X$;

$\diamond \quad X-$ Total no. of sessions for a year $=Y$;

$\diamond \frac{\mathrm{Y}}{\mathrm{X}}{ }^{*} 100=\%$ Shortfall in sessions per year

It is interesting to note the number of "Smart Link From" per year for the period 2010-2012 were: 9, 71 and 90 respectively (Table VII). When compared to the number of sessions per the years, this raises some concern regarding relevance and usefulness of the sessions, the search results and the Agricola database itself, as there is the indication that users search but the links to full text resources are nominal. Agricola showed a lower shortfall than Science Direct; this is in keeping with the studies by Atilgan and Bayram (2006, p. 90) and Coombs (2005, p. 603). 


\section{Questions 1-4 from the Questionnaire}

The following figures are presentations of the results generated through the use of SPSS.

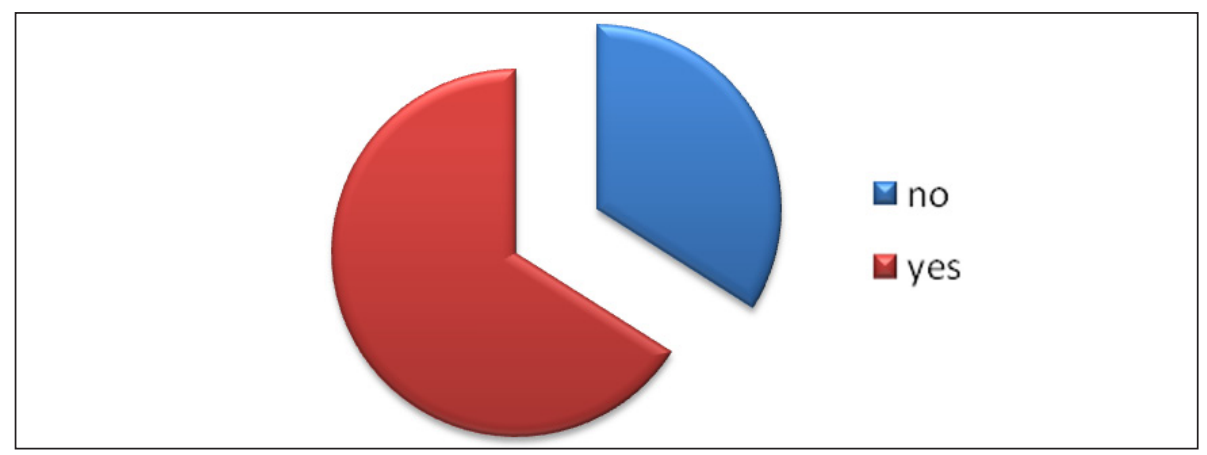

Figure 1. Awareness of e-resources (Results from Question \#1)

Figure 1 reveals $66 \%$ of the sample was aware of e-resources and $34 \%$ were not aware.

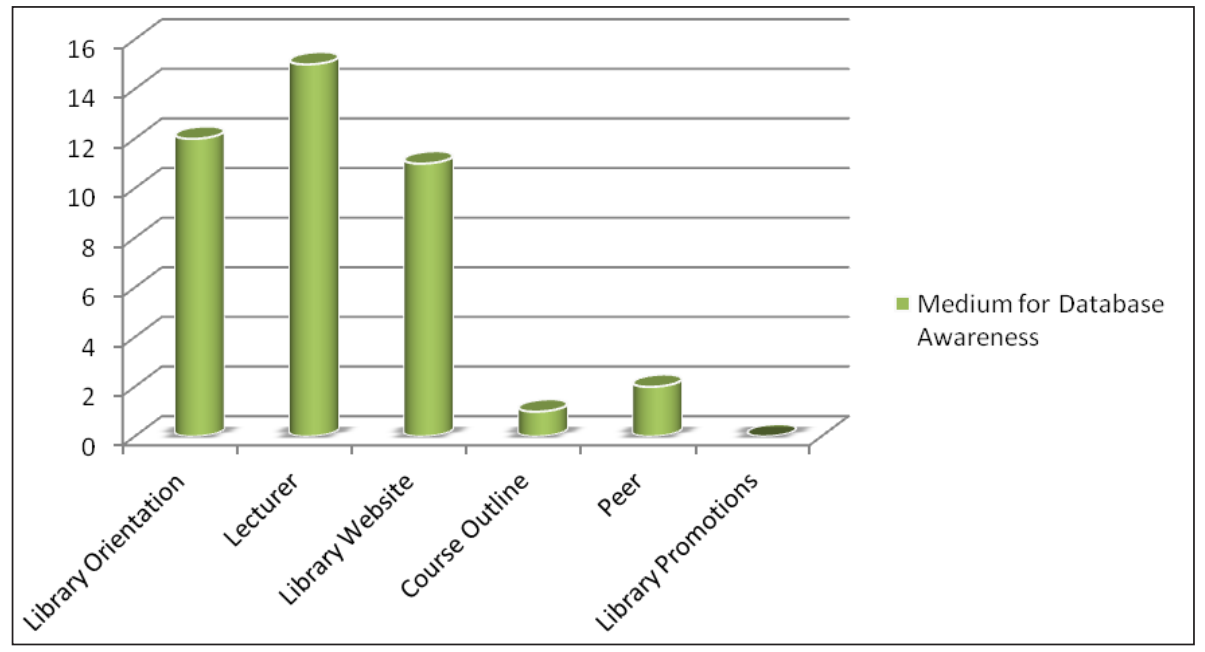

Figure 2. Medium for Database Awareness (Results from Question \# 2)

Figure 2 shows that $30 \%$ learnt about the library's e-resources from lecturers; $24 \%$ learnt from library orientation; $22 \%$ from library website; $4 \%$ from peer; $2 \%$ from course outline; and $0 \%$ from library promotions. Therefore the majority of the sample learnt about the existence of e-resources from lecturers and never from library promotions. 


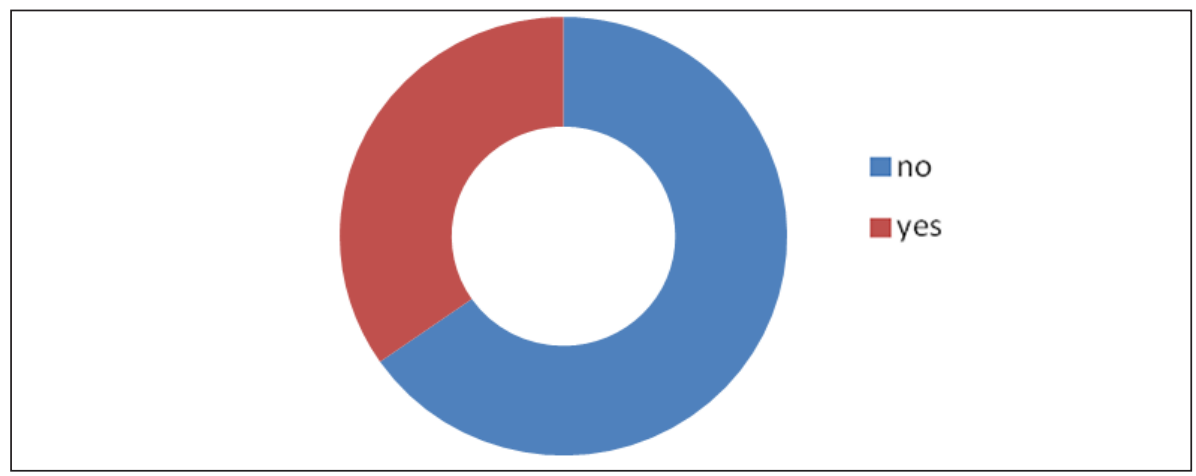

Figure 3. Use of E-resources (Results from Question \# 3)

Figure 3 shows that $64 \%$ of the respondents do not make use of the databases and only $34 \%$ use the databases.

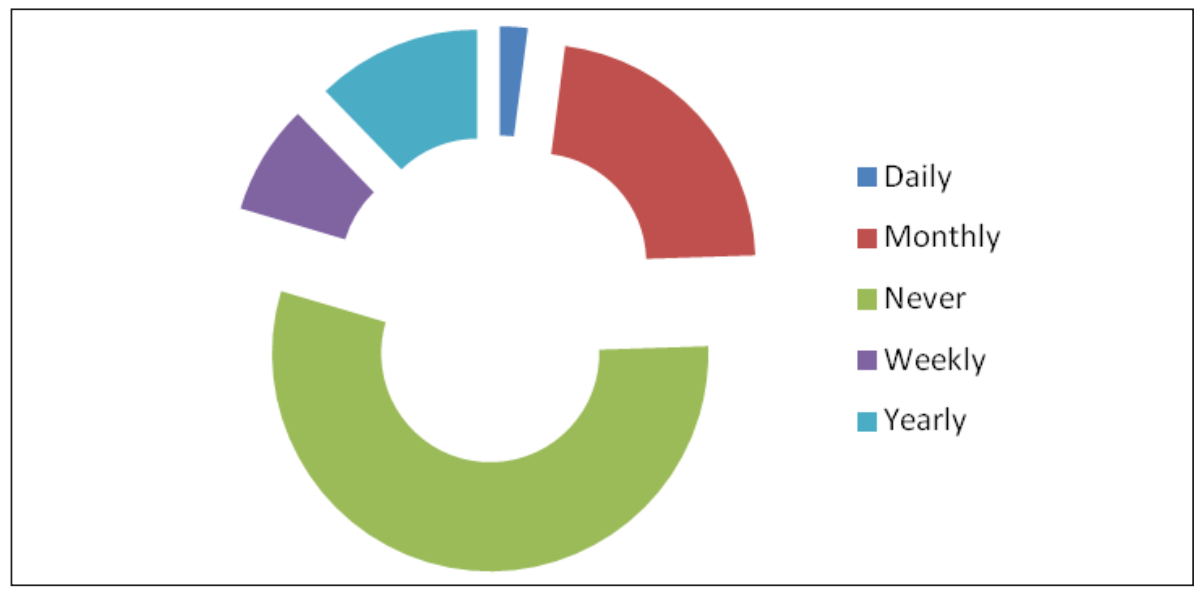

Figure 4. Frequency of Use of E-Resources (Results from Question \# 4)

Figure 4 indicates the majority of the sample, 54\%, said that they never used the databases. $22 \%$ used it monthly; $12 \%$ used it yearly; $8 \%$ weekly; and $2 \%$ daily. The responses from the questionnaire, as indicated in Figures 1- 4, reveal a similar trend with the results from the evaluation of Science Direct and Ebsco; the usage is consistently low. This general low usage is in keeping with studies such as Coombs (2005, p. 603); Atilgan \& Bayram (2006, p. 89); Dewald \& Silvius, (2005, p. 325) who too reported low usage. Given the composition of the sample, year 2, year 3, postgraduates and lecturers, this is particularly disconcerting as the expectation is that at this level they should at least be familiar with library electronic resources. The low and infrequent 
usage of the e-resources in food and agriculture somewhat challenges Salisbury et al. $(2012$, p. 250) claim that "in the sciences, faculty, researchers and graduate students are heavily dependent on subscription databases". It should however not go unnoted that food and agriculture is only one subset of the sciences. Additionally $66 \%$ were aware of the electronic databases yet only 34\% reported that they used these. This confirms Atilgan \& Bayram's (2006, p. 88) study which revealed that awareness of databases is not synonymous with use.

\section{Reasons for Usage}

Figure 5 shows that $38 \%$ of usage was for the purpose of completing assignments; $24 \%$ for professional research; $10 \%$ for exam preparations; $8 \%$ for preparing lectures; and $6 \%$ for providing information to remain current in the field. In this regard, the e-resources are largely used for assignments and professional research and least for keeping abreast with the trends in the field of food and agriculture. This is in keeping with studies by Bancroft et al. (1998), Tenopir et al. (2003), Bar-llan \& Fink (2005, p. 354), Dewald \& Silvius (2005, p. 325) which revealed that databases were primarily used for professional and scholarly purposes rather than personal needs.

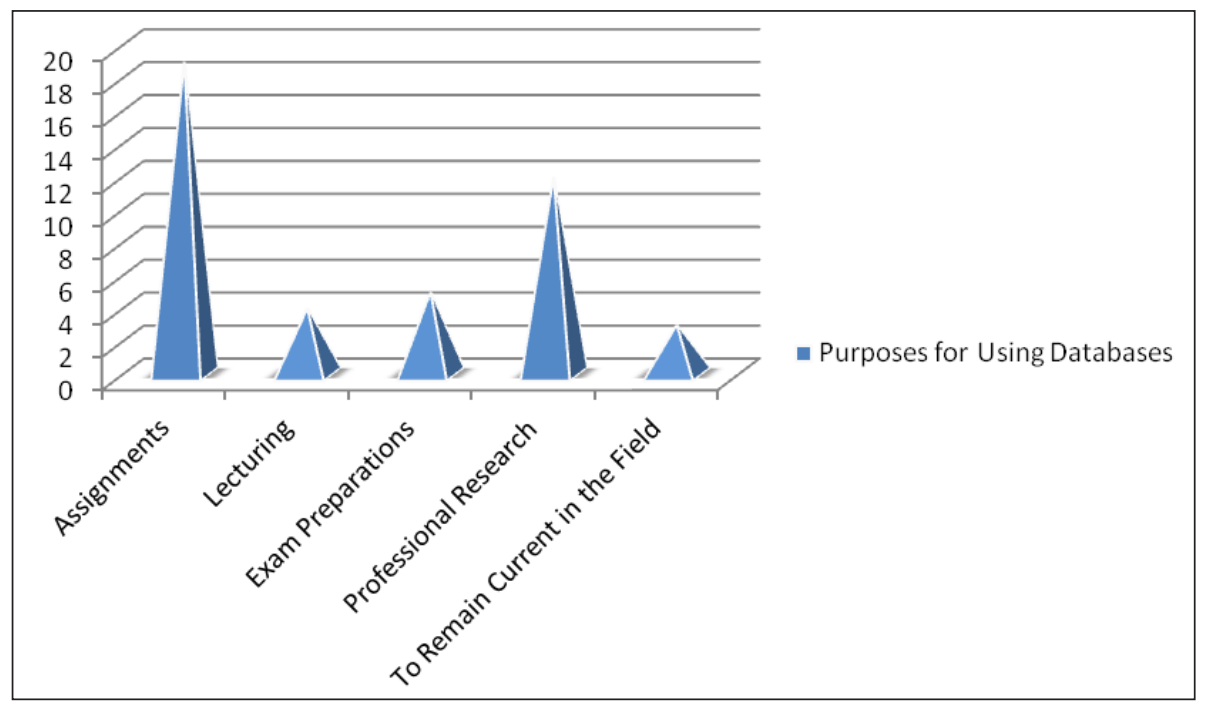

Figure 5. Results from Question \# 5: Purposes for Using E-Resources

Figure 6 reveals there are a number of factors encouraging the use, namely: ease of use, good menus and labelling, pertinence to research, reasonable results given, convenience, scholarly content, quickness, comfortability in using, accessibility and relevant content. Factors such as familiarity and information literacy skills did not influence their use of the databases. The scholarly content of the databases was the 
most influential factor (38\%) followed by pertinence to research (22\%) and relevant content (20\%).

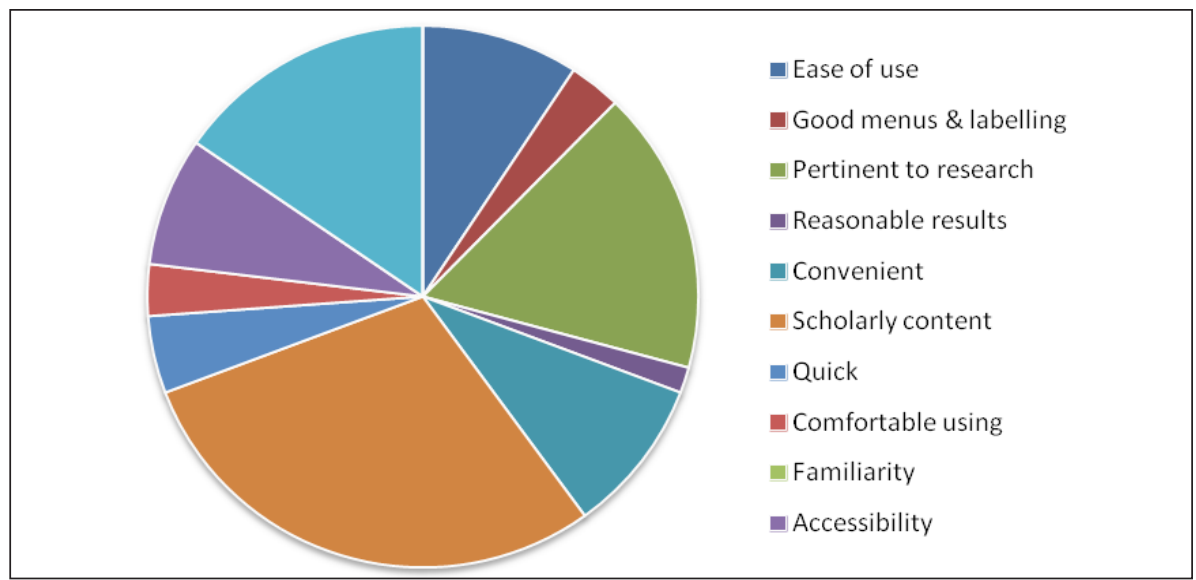

Figure 6. Factors Encouraging Use (Results from Question \# 6)

The least influential factors were: reasonable results (2\%); good menus and labeling (4\%); and feeling comfortable using (4\%). This is in keeping with studies such as Griffiths and Brophy (2005); Fast \& Campbell (2004, p. 138); Brophy (2005, p. 499, 509510); Salisbury et al., (2012, p. 256, 258); and Coombs (2005, p. 603) which showed that users often report they choose databases because of content rather than features. Yet it remains surprising that notwithstanding these, Google and Google Scholar get high usage rating because of features. Therfore, factors relating to the information source itself are the strongest encouragement for use rather than patron related factors and library related factors.

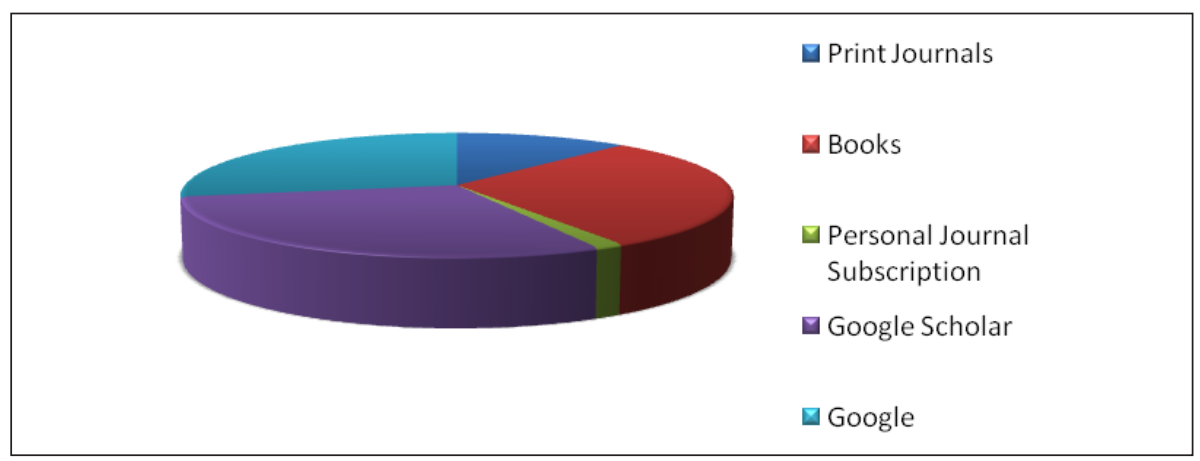

Figure 7. Sources of Information (Results from Question \# 7) 
Figure 7 shows that those who never used the e-resources noted they used instead print journals, books, personal journal subscriptions, Google and Google Scholar. $40 \%$ used Google Scholar; $40 \%$ books; 38\% Google; 2\% print journals and 2\% personal journal subscription. Google and Google Scholar in particular are the strongest reasons for non-use of the e-resources. The dependence on these indicates that these search engines are indeed a strong competition for electronic databases. This is consistent with studies by Griffiths \& Brophy (2005); Fast \& Campbell (2004, p. 138); Brophy (2005, p. 499, 509-510); Salisbury et al. (2012, p. 256, 258); and Coombs (2005, p. 603).

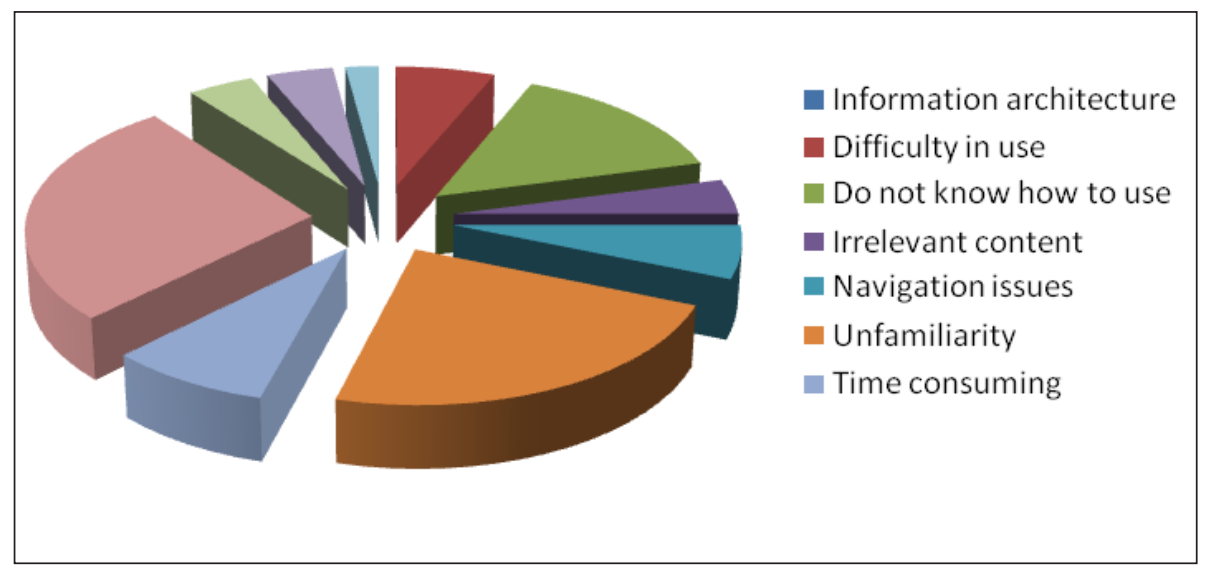

Figure 8. Factors Discouraging Use (Results from Question \# 8)

Figure 8 reveals difficulty in use, lack of knowledge, irrelevant content, navigation issues, unfamiliarity, time consuming nature, availability of other resources, complex menus and labeling and no Internet access at home are factors discouraging use. These factors discouraging use can be listed under three major headings, namely: library related, patron related and information source related. Availability of other sources (26\%), unfamiliarity (22\%) and lack of knowledge with regards to how to use the databases (14\%) were the major factors discouraging use. In this regard, patron related factors were the factors most influential in discouraging use. This is followed by information source related factor. No Internet access at home, complex menus and labeling, and irrelevant content are the factors that are the least discouraging and information architecture was not reported as an influence on non-use. A number of inferences can be drawn from these findings. Of importance is that they indicate access to technology is not a strong factor. Therefore, Law et al. $(2012$, p. 5) concern about students' access to technology can be laid to rest. Irrelevant content and complex menus and labeling being factors that are the least discouraging are consistent with the results on reasons that encourage use. This strengthens the point that content over features is more important with regards to usage of the electronic databases. 
Availability of other sources as the strongest influence on non-use reiterate the impact and strength of resources such as Google and Google Scholar especially given that 38\% and $40 \%$ of the sample were dependent on these respectively.

\section{Implications for Collection Development}

Only $34 \%$ reported use of the e-resources; only $22 \%$ used it monthly, which was the most frequent use; added to this is the $87.5 \%$ shortfall between expected usage and actual usage of the selected resources in Science Direct over the years 2010-2012. This low usage indicates a need for Mona librarians to revise or cancel some subscriptions within Science Direct. This gives support for Law et al. $(2012$, p. 12) recommendation that the library should focus on "a collection policy that focuses on supplying scholarly resources just as they are needed rather than just in case they are needed". This indeed would be a forward thinking approach. Additionally, as per table 5, the usage of agricultural resources within Science Direct indicates a downward trend per year. This consistency suggests a continued downward path in usage, which further strengthens the need to evaluate with the view to revise or cancel the current subscriptions. Similarly, Ebsco had a significant shortfall between expected usage and actual usage. For the years 2010-2012 the average shortfall per year was $64.2 \%$. Albeit a lower shortfall than Science Direct there is concern and as such the subscription should be reviewed. This is further strengthened by the figures for the number of "Smart Link From". This strongly suggests that the sessions are not relevant or that users are not doing effective searches. If subscription to this database is to continue, training in conducting effective search will be required.

The scholarly content of the databases, pertinence to research and relevant content were the most influential factors. This suggests that in terms of collection development, Mona librarians should continue to ensure the e-resources they select score high on content. In this regard librarians will need to review course outlines, find creative ways of encouraging dialog with lecturers as well as students regarding the materials to be purchased. It also suggests that they need to stay abreast of what is being published and given a good rating in the field. Notwithstanding this, librarians should be mindful that Google and Google Scholar get high usage rating because of features. Therefore, some balance is needed. The low usage raises questions on relevance of the resources to lecturers and students. Is it that the resources provided are not relevant? Of the $34 \%$ of respondents who answered that they use the e-resources $22 \%$ said they were pertinent to their research and $20 \%$ that they had relevant content. Of the $64 \%$ of respondents who answered that they never used the e-resources $4 \%$ cited irrelevant content as a reason for their non-use. These figures suggest that the e-resources selected have relevance to the work they do. 


\section{Implications for Research Throughput}

Undergraduates and postgraduates in food and agriculture are not heavily dependent on subscription e-resources to support their term papers and presentations. Similarly, lecturers are not dependent on the electronic resources in food and agriculture provided by the university to support their teaching and professional research. Both groups are largely dependent on Google, Google Scholar and books. The particular high dependence of $38 \%$ of the sample on Google raises concern on the quality of the information sources used to inform lectures, term papers and publications in food and agriculture especially given that Google is not predominantly scholarly or predominantly a container of peer-reviewed information resources. It also raises question on how faculty and students follow current trends and patterns in food and agriculture when 38\% are dependent on Google, $40 \%$ are dependent on Google Scholar and books; while only $16 \%$ are dependent on print journals and the majority are not using the subscribed resources. If these are an important means of maintaining food and agriculture communication and if only $34 \%$ use these, this raises concern regarding the extent to which scientific communication is happening and underscores the need to encourage greater usage. It also indicates that terms papers, presentations, lectures and publications are hardly, if at all influenced by these subscription e-resources.

\section{Encouraging Greater Use}

Figure 9 highlights respondents' recommendations to increase usage. Training sessions embedded in at least one course (52\%); the inclusion of subscription resources on the course outline (48\%); linking assignments to subscription e--resources (46\%); and circulating a listing of e-resources relevant to each course $(44 \%)$ were significantly the highest recommendations. The least favored recommendations were: university's administration should mandate the use of only online resources (4\%); more marks should be allotted to subscription e-resources (8\%); and the implementation of a mandatory semester long three credit course on library resources (12\%). Together these recommendations indicate the role of three key players and as such can be discussed under these headings. 


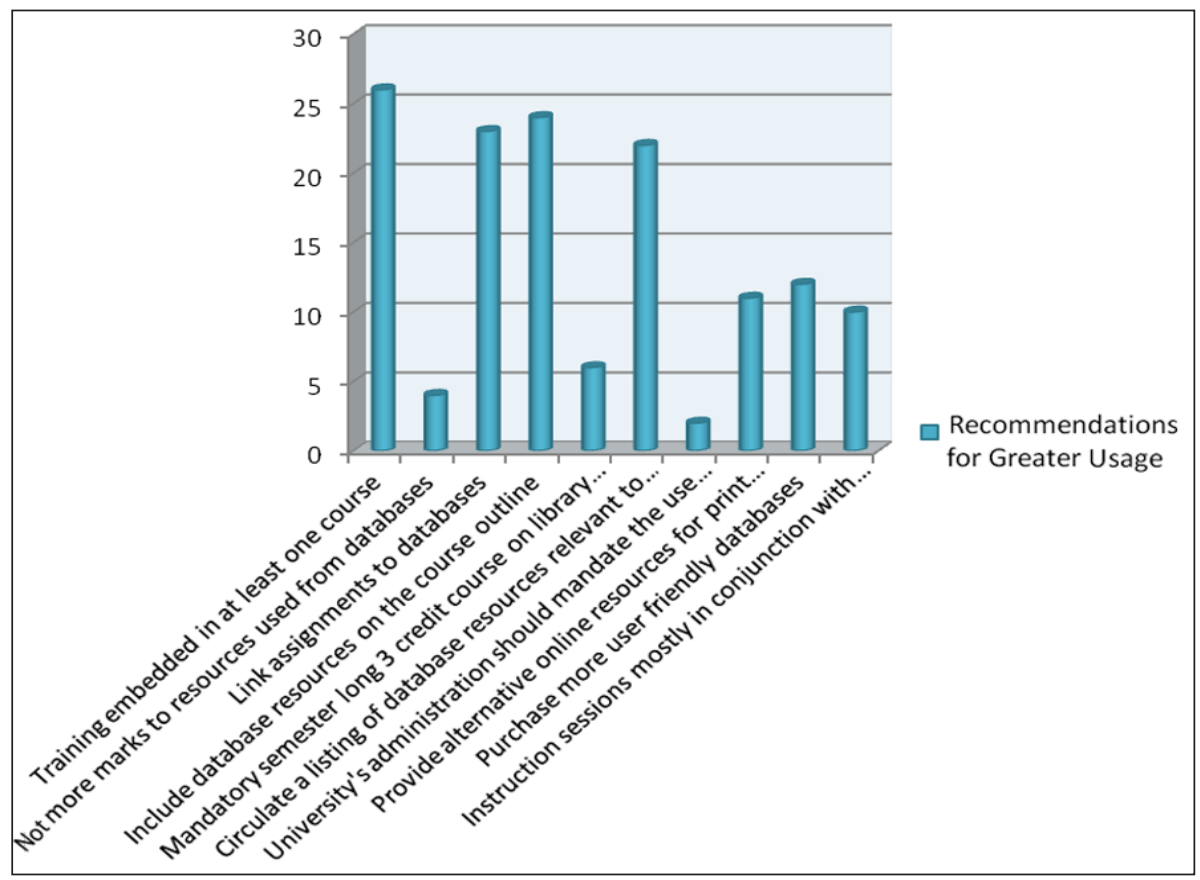

Figure 9. Recommendations for Greater Usage (Results from Question \# 9)

\section{University Administration and Faculty}

The results showed that the most frequent source for learning about library subscription e-resources was lecturers. This suggests incorporating lecturers into the promotional policy is critical. The library should therefore ensure lecturers are first aware of the e-resources by providing training sessions for them and then having them inform their students about these. The indication by $52 \%$ of the sample that training sessions should be embedded in at least one course further highlights the role of faculty in encouraging usage. In keeping with the previous suggestion for lecturers to inform students, one of the ways in which this could be achieved is through the use of the course outline. Faculty should identify a core first level course that students in the food and agriculture programme would have to complete before they are eligible for graduation; faculty should partner with the library in this regard and also in structuring this course to facilitate the embedding of modules on database access and usage. As 38\% of usage of the e-resources is for the purpose of completing assignments, which is the largest use, the suggestion by $46 \%$ of the sample to link assignments to e-resources seems practical. Given $66 \%$ of the sample were aware of the e-resources but were not making use of them, is indication of the need for a greater initiative to encourage use after 
making them aware. Therefore, this particular suggestion to link assignments with e-resources seems particularly practical. Law, Hemmasi and Baxmeyer's (2012, p.12) recommendation that the university's senior administration should mandate that going forward all teaching and research materials should be acquired and made available in online form was not highly favored as a recommendation by the sample. This raises questions on users' readiness for electronic library support.

\section{Library}

$44 \%$ of the sample recommended the circulation of a listing of e-resources relevant to each course. In this regard each subject librarian or liaison librarian could be given the target of identifying the e-resources relevant to their subject area of responsibility. They could go a step further by identifying key journals within each database relevant to the subject area of their responsibility and submit these on a semester or yearly basis to the lecturers in these areas. The fact that $0 \%$ learnt about the e-resources through library promotions suggests library promotions are not effective. There is the indication that the library should review their methods of e-resources promotion. Patron related factors were the most influential factors discouraging use. This is indication of the need to train users. Based on the response, the earlier suggestions listed under faculty are ideal. It is interesting that there were no technology related recommendations for increasing usage. This indicates users are comfortable with the current level of technology needed to access these resources. This is further confirmed by the fact that only $6 \%$ noted quickness as a factor encouraging use. This however should not be used to encourage complacency on the library's part.

\section{Conclusion}

The usage of food and agricultural subscription e-resources is very low. The shortfall between expected usage of food and agriculture e-resources and actual usage is significantly wide. There is also the indication that awareness of usage is not an automatic motivator for usage. "Never" was the most prominent indicator of how frequently subscription e-resources were used. However, when they were used it was largely for professional research and completion of assignments. The factors that mostly encouraged usage were content related factors, namely: scholarly content and pertinence to research. The factors that mostly discouraged usage were: information source related (availability of other sources) and patron related (unfamiliarity). This highlights the impact of competition from other information resources such as Google and Google Scholar and also to the need for training. In this regard, it was not surprising that the most popular recommendations to increase usage were: training sessions embedded in at least one course; the inclusion of subscription e-resources on the course outline; linking assignments to these; and circulating a listing of subscription e-resources relevant to each course. These recommendations will require the input and collaboration of University administration, faculty and the library. Interestingly, 
students' recommendations for encouraging greater use did not include any initiatives that they could engage in partnership with the library or with faculty or by themselves. This suggests the need for students to engage a greater part of the responsibility of their training and education. The implications for collection development point largely to the need to evaluate existing subscription with the view to cancelling all or some. In this regard supplying scholarly resources just as they are needed seem to be forward thinking. The implications for research throughput point largely to the absence of materials from electronic databases being used to inform throughput. There is the indication that throughput is largely influenced by Google Scholar and books and mainly non-scholarly information resources such as Google.

\section{References}

Atilgan, D., \& Bayram, O. G. (2006). Perspectives on an evaluation of faculty use of the digital library at Ankara University, Turkey. Journal of Academic Librarianship, 32(1), 86-93.

Bancroft, A.F., Croft, V.F., Speth, R., \& Philips, D.M. (1998). A forward looking library use survey: WSU libraries in the 21st century. Journal of American Librarianship, 24, 216-224.

Bar-llan, J., \& Fink, N. (2005). Preference for electronic format of scientific journals-a case study of the science library users at the Hebrew University. Library and Information Science Research, 27(3), 363-376.

Bar-llan, J., Peritz, B.C. \& Wolman, Y. (2003). A survey on the use of electronic databases and electronic journals accessed through the Web by the academic staff of Israeli Universities. Journal of Academic Librarianship, 29(6), 346-361.

Bell, S. (2004). The infodiet: How libraries can offer an appetizing alternative to Google. The Chronicle of Higher Education, 50(24). Retrieved from http://chronicle.com/

Brophy, J., \& Bawden, D. (2005). Is Google enough? Comparison of an Internet search engine with academic library resources. Aslib Proceedings 57(6), 498-512. Retrieved from http://www.soi.city.ac.uk/ dbawden/bawden\%20and\%20brophy 20ap.pdf

Coombs, K. A. (2005). Lessons learned from analyzing library database usage data. Library Hi Tech, 23(4), 598-609.

Dewald, N.H., \& Silvius, M.A. (2005). Business faculty research: Satisfaction with the Web versus library databases. Libraries and the Academy, 5(3), 313-328.

Dilek-Kayaoglu, H. (2008). Use of electronic journals by faculty at Istanbul University, Turkey: The results of a survey. Journal of Academic Librarianship, 34(3), 239- 247.

Fast, K.V., \& Campbell, G.D. (2004). "I still like Google”: University student perceptions of searching OPACs and the web by: Proceedings of the American Society for Information Science and Technology, 41(1), 138-146. doi:10.1002/meet.1450410 116

Griffiths, J.R., \& Brophy P. (2005). Student searching behavior and the Web: Use of academic resources and Google. Library Trends, 53(4), 539-554.

Law, M., Hemmasi H. \& Baxmeyer J. (2012). Library review: University of the West Indies, July 2012. Kingston, Jamaica. 
Presidents and Fellows of Harvard College. (2012). Faculty advisory council memorandum on journal pricing: Major periodical subscriptions cannot be sustained. Retrieved from http:// isites.harvard.edu/icb/icb.do?keyword=k77982\&tabgroupid=icb.tabgroup143448prm/ weekly/v50/i24/24b01501.htm

Salisbury, L., Laincz, J. \& Smith, J.J. (2012). Students' preferences in selecting information resources used to find scholarly information: A comparative study between undergraduate and graduate students. Journal of Agriculture \& Food Information, 13(3), 250-266.

Sample, I. (2012, April 24). Harvard University says it can't afford journal publishers' prices. The Guardian. Retrieved from http://gu.com/p/375vj/em.

Tenopir, C., King, D.W., Boyce, P., Grayson, M., Zhang, Y. \& Ebuen, M. (2003). Patterns of journal use by scientists through three evolutionary phases. D-Lib Magazine, 9. Retrieved from http:// www.dlib.org/dlib/may03/king/05king.html

Yue, P.W. \& Syring M.L. (2004). Usage of electronic journals and their effect on interlibrary loan: A case study at the University of Nevada, Reno. Library Collections, Acquisitions \& Technical Services, 28, 420-432. 